\title{
META-ANALISIS COOPERATIVE LEARNING TERHADAP KEMAMPUAN BERPIKIR KRITIS PADA PEMBELAJARAN IPA/ FISIKA SISWA
}

\author{
Syafrial ${ }^{1}$ \\ ${ }^{1}$ Program Studi Tadris Fisika, IAIN Kendari \\ Email: syafrialkonda@gmail.com
}

\begin{abstract}
ABSTRAK
Meta-analisis ini bertujuan untuk merangkum hasil penelitian tentang pengaruh cooperative learning (CL) untuk meningkatkan kemampuan berpikir kritis siswa sehingga dapat diketahui: besar effect size (ES) rata-rata, tipe CL yang mempunyai effect size (ES) paling besar dan konsisten terhadap peningkatan berpikir kritis siswa. Metode penelitian yang digunakan adalah deskriptif dengan bentuk penelitian survei. Jumlah hasil penelitian yang dirangkum adalah 19 artikel jurnal. Hasil analisis data menghasilkan bahwa ES sebesar 0,71. (berkontribusi sebesar 26, 32\%). Tipe CL yang menghasilkan pengaruh paling besar dan konsisten adalah Type Problem Basic Learning (ES = 1,08, berkonstribusi sebesar 17,97\%). Pada jenjang pendidikan yang berbeda, CL berkonstribusi besar pada tingkat SMA yaitu (ES = 0,79, berkontribusi sebesar 35,33\%)
\end{abstract}

Kata kunci: Meta-analisis, cooperative learning, peningkatan berpikir kritis

\begin{abstract}
This meta-analysis aims to summarize the results of research on the effect of cooperative learning to improve students' critical thinking skills so that it can be seen: the average effect size (ES), the type of CL which has the largest and consistent effect size (ES) critical students. The research method used is descriptive with the form of survey research. The number of research results summarized is 19 journal articles. The results of the data analysis resulted in an ES of 0.71. (contributing 26, 32\%). The type of cooperative learning that produces the greatest and most consistent influence is the Basic Learning Type Problem (ES =1.08, contributing 17.97\%). At the level of education CL the contribution is large at the high school level, namely ( $E S=0.79$, contributing 35.33\%).
\end{abstract}

Keywords: Meta-analysis, cooperative learning, improvement in critical thinking

DOI: http://dx.doi.org/10.15575/jtlp.v3i1.6550

Received: 5 Mei 2018 ; Accepted: 31 Agustus 2018 ; Published: 1 September 2018 


\section{PENDAHULUAN}

Upaya peningkatan mutu pendidikan dan profesionalisme guru seiring dengan pergeseran pola pikir dalam pembelajaran yang melahirkan paradigma baru dalam pembelajaran Paradigma baru muncul karena terjadinya anomali-anomali dalam dunia pendidikan khususnya dalam proses belajar mengajar. Beberapa pemikiran yang dapat ditengarai sebagai paradigma baru dalam pembelajaran antara lain: (1) penetapan empat pilar pendidikan oleh UNESCO: learning to know, learning to do, learning to be, learning to life together sebagai paradigema pembelajaran; (2) kecendrungan bergesernya orientasi pembelajaran dari teacher centered ke student centered; (3) berubahnya kurikulum dari content based curriculum menuju competency based curriculum; (4) perubahan teori pembelajaran dari behavioristik menuju konstruktivistik; (5) perubahan pendekatan dari teoritis ke konstektual; (6) dari evaluasi dengan paper and pencil test yang hanya mengukur convergent thinking menuju autenthic assessment yang dapat mengukur divergent thinking (Arnyana, 2006: 2).

Perubahan paradigma pendidikan terjadi diberbagai bidang disiplin ilmu, begitu juga halnya terjadi pada Pembelajaran IPA. Pembelajaran IPA dalam kehidupan sehari-hari memiliki peranan yang sangat penting dalam memahami fenomena-fenomena alam, sehingga dapat menjadi lebih arif dalam mengelola lingkungannya. Seiring dengan perkembangan ilmu pengetahuan maka diperlukan juga Sumber Daya Manusia (SDM) yang berkualitas. Untuk meningkatkan kualitas SDM di bidang IPA, maka perlu kiranya diterapkan Pembelajaran IPA yang lebih berkualitas. Kemampuan memilih model dan menerapkannya dalam proses pembelajaran sangat penting, karena kemampuan tersebut akan menjadikan pembelajaran yang efektif.

Salah satu model pembelajaran yang dianjurkan oleh para ahli adalah cooperative learning. Slavin dalam Sanjaya (2006) menyatakan bahwa (1) penggunaan CL dapat meningkatkan hasil belajar siswa sekaligus dapat meningkatkan kemampuan hubungan sosial, menumbuhkan sikap menerima kekurangan diri dan orang lain, serta dapat mmeningkatkan harga diri. (2) pembelajaran kooperatif dapat merealisasikan kebutuhan siswa dalam berpikir, memecahkan masalah, dan mengintegrasikan pengetahuan dengan keterampilan. Penelitian mengenai pengaruh CL pada pembelajaran berpikir kritis siswa telah banyak dilakukan dan hasilnya ternyata mengungkapkan bahwa CL mampu meningkatkan hasil belajar siswa. Namun dari sekian banyak penelitian itu dilakukan dengan menerapkan tipe CL yang berbeda-beda.

\section{METODE PENELITIAN}

Jenis penelitian pada penelitian ini adalah penelitian survei. Penelitian ini dilakukan dengan populasi kecil yaitu 19 artikel jurnal pendidikan cooperative learning dari 20032018. Sampel yang diambil adalah 19 artikel jurnal tentang pengaruh CL terhadap peningkatan berpikir kritis siswa pada pembelajaran IPA. Data yang dipelajari diambil dari sampel digunakan untuk menemukan hubungan CL dan berpikir kritis siswa pada pembelajaran IPA/ Fisika.

Prosedur dalam penelitian ini disesuaikan dengan langkah-langkah membuat meta-analisis yang disarankan oleh Glass dalam Sutrisno (2007). Adapun prosedur penelitian ini adalah sebagai berikut:

1. Tahap persiapan

a. Menetapkan domain berdasarkan,

- Variabel bebas: cooperative learning

- Variabel terikat: berpikir kritis siswa pada pembelajaran IPA

b. Menetapkan kriteria penelitian yang dirangkum

- Bentuk publikasi: artikel jurnal pendidikan

- Tahun publikasi: 2003-2018

- Definisi operasi variabel terikat: peningkatan berpikir kritis siswa pada pembelajaran IPA adalah meningkatnya berpikir kritis yang diperoleh siswa, baik pretest maupun 
posttest yang dinyatakan dalam bentuk skor

2. Tahap pelaksanaan

a. Mencari dan mengumpulkan artikel jurnal

b. Mengekstrak penelitian mencakup

- Variabel peneliti: identitas peneliti

- Variabel sasaran: jenjang sekolah yang terdiri atas SD, SMP dan SMA

- Variabel metodologi: jenis penelitian yang digunakan, analisis statistik yang digunakan, teknik sampling yang digunakan

c. Menghitung effect size per penelitian

d. Menganalisis effect size: menghitung rata-rata (mean) dan simpangan deviasi.

e. Menganalisis hubungan antar variabel

f. Membuat rangkuman dalam sebuah laporan ilmiah

3. Tahap analisis data

a. Menganalisis effect size berdasarkan: variabel sasaran, variabel metodologi.

b. Menganalisis effect size variabel moderator lain yang ditemukan seperti, tipe coopertive learning yang dipakai,

c. Menganalisis hubungan antar variabel

- Jenjang sekolah dengan model cooperative learning.

\section{HASIL DAN PEMBAHASAN}

Pada penelitian ini jumlah artikel jurnal CL yang sesuai dengan tujuan penelitian adalah 19 judul artikel jurnal. Adapun rinciannya ditampilkan pada Tabel 1.

Tabel 1. Kategori Efek Size Artikel

\begin{tabular}{lccc}
\hline No & Tipe & ES & Kategori \\
\hline 1 & PB & 1,52 & \\
2 & ST & 1,52 & \\
3 & PB & 1,42 & Sangat Kuat \\
4 & PB & 1,42 & \\
5 & PBL & 1,13 & \\
\hline 6 & PBL & 0,98 & \\
7 & CS & 0,89 & \\
8 & PB & 0,86 & \\
9 & JS & 0,81 & \\
10 & NH & 0,75 & \\
11 & GI & 0,69 & Kuat \\
12 & GI & 0,68 & \\
13 & TP & 0,59 & \\
14 & ST & 0,53 & \\
15 & NH & 0,30 & \\
\hline 16 & PB & 0,19 & Sedang \\
17 & TW & 0,19 & \\
\hline 18 & PBL & 0,07 & Lemah \\
19 & PBL & - & \\
\hline
\end{tabular}

Dari hasil perhitungan harga effect size diperoleh rata rata Efect Size sebesar 0,71. Ini berarti bahwa penerapan CL dapat meningkatkan berpikir kritis pada pembelajaran IPA siswa sebesar 26, 32\%. Harga effect size yang dihasilkan terkategorikan sedang. Adapun secara rinci informasi efek size dari artikel jurnal disajikan pada Tabel 2.

Tabel 2. Besarnya Efek Size Artikel

\begin{tabular}{|c|c|c|c|c|c|c|c|c|}
\hline No & Tahun & Nama & $\mathrm{Ne}$ & nc & $\mathrm{Xe}$ & $\mathrm{Xc}$ & SD & ES \\
\hline 1 & 2012 & Widiarini. P & 63 & 63 & 49,44 & 37,59 & 8,36 & 1,42 \\
\hline 2 & 2013 & IK Ardana, I.B.P Arnyana, I.G.A.N. Setiawan & 34 & 34 & 76,25 & 67,13 & 5,99 & 1,52 \\
\hline 3 & 2013 & Tiara Irmawati, Budi Handoyo, Purwanto & 35 & 35 & 61,2 & 54,8 & 8,57 & 0,75 \\
\hline 4 & 2013 & $\begin{array}{l}\text { Nurul Iva, Aloysius Duran Corebima, } \\
\text { Triastono Imam Prasetyo }\end{array}$ & 21 & 21 & 68,5 & 61,36 & 8,03 & 0,89 \\
\hline 5 & 2014 & $\begin{array}{l}\text { M.Abdurrahman Sunni, Wartono, Markus } \\
\text { Diantoro }\end{array}$ & 35 & 35 & 75,05 & 74,66 & 2,08 & 0,19 \\
\hline 6 & 2014 & Mujahidah & 35 & 35 & 82,14 & 74,4 & 11,4 & 0,68 \\
\hline 7 & 2016 & $\begin{array}{l}\text { Nurhikmah, Endang Budiasih, Aman } \\
\text { Santoso }\end{array}$ & 20 & 20 & & & & \\
\hline
\end{tabular}




\begin{tabular}{|c|c|c|c|c|c|c|c|c|}
\hline No & Tahun & Nama & $\mathrm{Ne}$ & $\mathrm{nc}$ & $\mathrm{Xe}$ & $\mathrm{Xc}$ & SD & ES \\
\hline 8 & 2016 & $\begin{array}{l}\text { Nursyamsi SY, Aloysius Duran, Herawati } \\
\text { Susilo }\end{array}$ & 30 & 30 & 66,27 & 64,53 & 5,75 & 0,30 \\
\hline 9 & 2017 & Nuraini Rizki Sari & 36 & 36 & 80,72 & 75,91 & 6,78 & 0,07 \\
\hline 10 & & $\begin{array}{l}\text { Dewi Insyasiska, Siti Zubaidah, Herawati } \\
\text { Susilo }\end{array}$ & 27 & 28 & 84,0 & 78,9 & 5,19 & 0,98 \\
\hline 11 & 2011 & Eka Triyuningsih & & & 62,25 & 54,42 & 9,01 & 0,86 \\
\hline 12 & 2012 & - & 63 & 63 & 49,44 & 37,59 & 8,36 & 1,42 \\
\hline 13 & 2014 & $\begin{array}{l}\text { Luh Siratman, Ngurah Marhaeni, Nyoman } \\
\text { Dantes }\end{array}$ & 26 & 26 & 18,42 & 21,23 & 1,42 & 0,19 \\
\hline 14 & 2014 & L. Surayya, I.W Subagya, I.N. Tika & 59 & 58 & 69,27 & 661,45 & 13,1 & 0,59 \\
\hline 15 & 2015 & Risa Hartati, Hayat Sholihin & 25 & 25 & 70,37 & 62,81 & . & - \\
\hline 16 & 2018 & Fahmi Nur Hidayat, Widhy Astuti & 28 & 28 & 75,54 & 61,25 & 9,32 & 1,52 \\
\hline 17 & 2013 & $\begin{array}{l}\mathrm{Ni} \text { Wayan Piasih Arianti,I Wayan } \\
\text { Lasmawan, Nyoman Dantes }\end{array}$ & 88 & 88 & 38,31 & 30,69 & 9,42 & 0,81 \\
\hline 18 & 2015 & $\begin{array}{l}\text { I Ketut Budiastra, Dewa Nyoman Sudana, } \\
\text { Nyoman Arcana }\end{array}$ & 26 & 21 & 41,7 & 39,05 & 3,84 & 0,69 \\
\hline 19 & 2014 & I Gd Surata, A.A Gede Agung, Km Sudarma & 26 & 26 & 36,73 & 33,57 & 5,94 & 0,53 \\
\hline
\end{tabular}

Selanjutnya data pada Tabel 1 dan 2 dikelompokkan bedasarkan tipe CL-nya, ditunjukkan oleh Tabel 3.

Tabel 3. Effect size berdasarkan tipe CL

\begin{tabular}{|c|c|c|c|}
\hline Tipe & $\begin{array}{l}\text { Jumlah } \\
\text { artikel }\end{array}$ & SD & ES \\
\hline $\begin{array}{l}\text { Problem Basic } \\
\text { Learning }\end{array}$ & 5 & 7,43 & 1,08 \\
\hline $\begin{array}{l}\text { Project Based } \\
\text { Learning }\end{array}$ & 4 & 3,99 & 0,70 \\
\hline$S T A D$ & 2 & 5,97 & 1,03 \\
\hline $\begin{array}{l}\text { Numbered Head } \\
\text { Together }\end{array}$ & 2 & 7,16 & 0,53 \\
\hline $\begin{array}{l}\text { Tipe GI (Group } \\
\text { Investigation) }\end{array}$ & 2 & 7,12 & 0,19 \\
\hline $\begin{array}{l}\text { Cooperative } \\
\text { Script }\end{array}$ & 1 & 8,03 & 0,89 \\
\hline $\begin{array}{l}\text { Think-Talk- } \\
\text { Write (TWT) }\end{array}$ & 1 & 1,42 & 0,19 \\
\hline Think Pair Share & 1 & 13,1 & 0,59 \\
\hline Jigsaw & 1 & 9,42 & 0,81 \\
\hline
\end{tabular}

Tipe CL yang paling besar dan paling konsisten pengaruhnya adalah CL tipe Problem Based Learning ini mampu meningkatkan hasil belajar berpikir kritis siswa sebesar 17,97\%. Ada beberapa hal yang dapat dijadikan alasan mengapa model CL tipe Problem Based Learning mampu menghasilkan kontribusi yang besar pada peningkatan berpikir kritis siswa, hal ini diantaranya karena karakteristik dari Problem Based Learning yaitu: (1) memposisikan siswa sebagai self-directed problem solver melalui kegiatan kolaboratif, (2) mendorong siswa untuk mampu menemukan masalah dan mengelaborasinya dengan mengajukan dugaandugaan dan merencanakan penyelesaian, (3) memfasilitasi siswa untuk mengeksplorasi berbagai alternatif penyelesaian dan implikasinya,serta mengumpulkan dan mendistribusikan informasi, (4) melatih siswa untuk terampil menyajikan temuan, dan (5) membiasakan siswa untuk merefleksi tentang efektivitas cara berpikir mereka dalam menyelesaikan masalah.

Pada model CL tipe Problem Based Learning merupakan suatu pendekatan pembelajaran yang diawali dengan menghadapkan siswa dengan masalah IPA. Dengan segenap pengetahuan dan kemampuan yang telah dimilikinya, siswa dituntut untuk menyelesaikan masalah yang kaya dengan konsep-konsep IPA. 
Tabel 4. Efek Size berdasarkan jenjang sekolah

\begin{tabular}{ccccc}
\hline $\begin{array}{c}\text { Jenjang } \\
\text { Sekolah }\end{array}$ & $\begin{array}{c}\text { Jumlah } \\
\text { artikel }\end{array}$ & ES & DS & KV \\
\hline SD & 3 & 0,68 & - & - \\
SMP & 6 & 0,76 & - & - \\
SMA & 10 & 0,79 & - & - \\
\hline
\end{tabular}

Berdasarkan harga effect size yang dihasilkan penerapan CL di SD mampu meningkatkan berpikir kritis siswa sebesar 30,05\%, untuk di SMP sebesar 34,08 \%, dan untuk di SMA sebesar $35,43 \%$. Di SMA lebih efektif merupakan hal yang logis sebab, sesuai dengan tingkat kematangannya (utamanya dalam pengalaman dan usia), seseorang akan menjadi lebih mandiri dalam banyak hal, termasuk di dalam belajar secara berkelompok sehingga ia mampu bertindak sesuai perannya di kelompok tersebut. CL merupakan model pembelajaran yang akan baik diterapkan pada siswa yang paham dengan tipe kerjasama yang dibutuhkan. Pemahaman ini muncul pada siswa yang telah memiliki pemikiran yang matang. Di tingkat sekolah menengah pertama, dalam pembelajaran kelompok siswa cenderung membebankan tugas pada salah satu siswa yang dianggap lebih pintar dari anggota kelompok yang lain.

Tabel 5. Kriteria Kategori Efek Size

\begin{tabular}{rccc}
\hline Rentang & Kategori & $\begin{array}{r}\text { Jumlah } \\
\text { Artikel }\end{array}$ & $\begin{array}{c}\text { Persentase } \\
(\%)\end{array}$ \\
\hline $0,00-0,10$ & Lemah & 0 & 0 \\
$0,10-0,25$ & Sedang & 3 & 0,16 \\
$0,25-0,40$ & Kuat & 11 & 0,58 \\
$>0,40$ & Sangat & 5 & 0,26 \\
& Kuat & & \\
\hline
\end{tabular}

Dari hasil kriteria Efek Size dengan beberapa kategori, kategori yang terbanyak adalah kategori kuat sebesar $58 \%$, hal ini menunjukan bahwa berbagai tipe CL yang digunakan dapat meningkatkan berpikir kritis siswa, walaupun perlu di cremati pula penggunaan model cooperatif learning dengan tipe tertentu hubungannya dengan konten materi mata pelajaran tersebut.

\section{KESIMPULAN}

Berdasarkan hasil meta-analisis yang telah dilakukan maka dikemukakan beberapa kesimpulan sebagai berikut (1) effect size ratarata pengaruh penerapan cooperative learning pada peningkatan hasil belajar berpikir kritis siswa adalah sebesar 0,71. Itu berarti bahwa penerapan CL memberikan kontribusi sebesar $26,32 \%$ dalam meningkatkan kemampuan berpikir kritis siswa. (2) Tipe CL yang paling baik pengaruhnya adalah CL tipe Problem Basic Learning dengan EZ $=1,08$. Penerapan coopeartive learning tipe Problem Basic mampu memberikan kontribusi sebesar 17,97 \% pada peningkatan berpikir kritis siswa.

Berdasarkan jenjang sekolah efek size yang paling tinggi ada pada tingkat SMA 35,43\%, hal ini dapat di jelaskan bahwa, pengaruh usia SMA sangat besar konstribusinya, karena semakin dewasa seseorang maka keberanian berpikir kritis semakin tinggi pula.

\section{DAFTAR PUSTAKA}

Andriani, I. S., Corebima, A. D., \& Prasetyo, T. I. (2013). Pengaruh Penerapan Model Pembelajaran Cooperative Script Terhadap Kemampuan Berpikir Kritis Dan Hasil Belajar Siswa Kelas Xi Sma Di Kota Malang. Skripsi Tidak Diterbitkan. Malang: Fakultas Ilmu Sosial Universitas Negeri Malang

Ardana, I. K., Arnyana, I. B. P., \& Setiawan, I. G. A. N. (2013). Studi Komparatif Penerapan Model Pembelajaran Berbasis Masalah Dan Model Pembelajaran Kooperatif Tipe Stad Terhadap Keterampilan Berpikir Kritis Dan Kinerja Ilmiah Biologi Sma. Jurnal Pendidikan Dan Pembelajaran Ipa Indonesia, 3(1).

Ariyanti, N. W. P., Lasmawan, I. W., \& Dantes, N. (2013). Pengaruh Model Pembelajaran Kooperatif Tipe Jigsaw Terhadap Kemampuan Berpikir Kritis Dan Prestasi Belajar Siswa Dalam Pembelajaran Ips Pada 
Siswa Kelas Iv Sd Cipta Dharma Denpasar. Pendasi: Jurnal Pendidikan Dasar Indonesia, 3(1).

Bimantara, R., Nasir, M., \& Rahmad, M. Penerapan Model Pembelajaran Guided Discovery Untuk Meningkatkan Keterampilan Berpikir Kritis Siswa Kelas Xi Sma N 9 Pekanbaru Dalam Pembelajaran Fisika. Jurnal Online Mahasiswa Fakultas Keguruan Dan Ilmu Pendidikan Universitas Riau, 3(1), 1-11

.Budiastra, I. K., Sudana, D. N., \& Arcana, I. N. (2015). Pengaruh Model Kooperatif GI (Group Investigation) Terhadap Keterampilan Berpikir Kritis Dalam Pembelajaran IPA. Mimbar Pgsd Undiksha, 3(1).

Dewi, M. K., Santyasa, I. W., Si, M., \& Warpala, I. W. S. (2014). Pengaruh Model Pembelajaran Berbasis Masalah Terhadap Pemahaman Konsep Fisika Dan Keterampilan Berpikir Kritis Siswa Kelas. Jurnal Teknologi Pembelajaran Indonesia, 4

Hartati, R., \& Sholihin, H. (2015). Meningkatkan Kemampuan Berpikir Kritis Siswa Melalui Implementasi Model Problem Based Learning (PBL) Pada Pembelajaran IPA Terpadu Siswa SMP. Prosiding Simposium Nasional Inovasi dan Pembelajaran Sains 2015, 505-508.

Hidayat, F. N., \& Hastuti, P. W. (2018). Pengaruh Model Problem Based Learning Dengan Strategi Mind Mapping Pada Pembelajaran Ipa Terhadap Kemampuan Berpikir Kritis Siswa Smp. Pend. Ilmu Pengetahuan AlamS1, 7(6), 298-303.

Hikmah, N., Budiasih, E., \& Santoso, A. (2016). Pengaruh Strategi Project Based Learning (Pjbl) Terhadap Kemampuan Berpikir Kritis Siswa Kelas Xi Ipa Pada Materi Koloid. Jurnal Pendidikan: Teori, Penelitian, Dan Pengembangan.

Insyasiska, D., Zubaidah, S., \& Susilo, H. (2017). Pengaruh Project Based Learning Terhadap Motivasi Belajar, Kreativitas, Kemampuan Berpikir Kritis, Dan Kemampuan Kognitif
Siswa Pada Pembelajaran Biologi. Jurnal Pendidikan Biologi, 7(1)

Kusumaningtias, A., Zubaidah, S., \& Indriwati, S. E. (2013). Pengaruh Problem Based Learning Dipadu Strategi Numbered Heads Together Terhadap Kemampuan Metakognitif, Berpikir Kritis, Dan Kognitif Biologi. Jurnal Penelitian Kependidikan, 23(1), 33-47.

Nursyamsi, S. Y., Duran, A., \& Susilo, H. (2016). Pengaruh Strategi Pembelajaran Numbered Heads Together (Nht) Terhadap Keterampilan Berpikir Kritis Siswa Sma.

Sari, N. A. R. Pengaruh Model Pembelajaran Project Based Learning (Pjbl) Berbantuan Fotonovela Terhadap Kemampuan Berpikir Kritis Siswa Kelas Viii Smp Kartika Ii-2.

Sritaman, N. L., Marhaeni, A. N., \& Dantes, N. (2014). Pengaruh Implementasi Model Pembelajaran Kooperatif Dengan Teknik Ttw Dalam Rangka Meningkatkan Kemampuan Berpikir Kritis Dan Pemahaman Bacaan Pembelajaran Bahasa Indonesia. Jurnal Penelitian Dan Evaluasi Pendidikan Indonesia, 4.

Sunni, M. A., Wartono, W., \& Diantoro, M. (2014, October). Pengaruh Pembelajaran Problem Solving Berbantuan Phet Terhadap Penguasaan Konsep Fisika

Surata, I. G., Agung, A. G., \& Sudarma, K. (2013). Pengaruh Model Kooperatif STAD Berorientasi Open-Ended Problem Terhadap Keterampilan Berpikir Kritis Dalam Pembelajaran Ipa Siswa Kelas V Sekolah Dasar. Mimbar Pgsd Undiksha, 1(1).

Surayya, L., Subagia, I. W., Tika, I. N., \& Si, M. (2014). Pengaruh Model Pembelajaran Think Pair Share Terhadap Hasil Belajar Ipa Ditinjau Dari Keterampilan Berpikir Kritis Siswa. Jurnal Pendidikan Dan Pembelajaran Ipa Indonesia, 4(1).

Triyuningsih, E. (2011). Pengaruh Model Pembelajaran Berdasarkan Masalah (Prblem Based Learning) Terhadap Kemampuan Berpikir Kritis Siswa. 
Widiarini, P. (2012). Pengaruh Model Pembelajaran Berbasis Masalah Terhadap Keterampilan Berpikir Kritis Dan Pemahaman Konsep Fisika Ditinjau Dari Motivasi Belajar Siswa Kelas X Sma Negeri 1 Seririt. Jurnal Pendidikan Dan Pembelajaran Ipa Indonesia, 2(1). 